\title{
Flow Injection On-line Preconcentration of Trace Zinc(II) Ions in Water Samples Using a Synthesized 8-Hydroxyquinoline Functionalized Amberlite XAD-2 Resin and Determination by Flame Atomic Absorption Spectrometry
}

\author{
Reena Saxena* and Prem Lata Meena

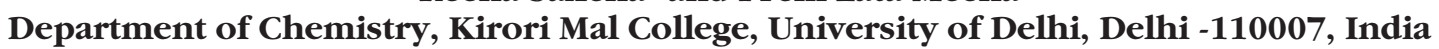

\begin{abstract}
An on-line flow injection preconcentration method for trace amounts of zinc at ppb (parts per billion) levels in real water samples was developed using flow injection flame atomic absorption spectrometry (FI-FAAS). A new chelating resin of 8-hydroxyquinoline functionalized Amberlite XAD-2 was synthesized, characterized, and used for complexation of zinc. Optimization of the flow injection variables was done for the determination and quantitative preconcentration of zinc. The sample acidity was adjusted to $\mathrm{pH} 8.0$ for the effective retention of zinc ions on the resin. The chelating resin can be reused for 90-100 cycles of sorption-desorption without any significant change in its activity. The adsorbed zinc ions were eluted with $0.3 \mathrm{~mol} \mathrm{~L}^{-1} \mathrm{HNO}_{3}$.

The calibration graph obtained
\end{abstract}

was found to be linear over the concentration range of 0 to $80 \mu \mathrm{g} \mathrm{L}^{-1}$. An enhancement factor of 137 -fold for a sample volume of $15 \mathrm{~mL}$ was obtained by using the time-based technique. The detection limit for the preconcentration method was found to be 0.33 $\mu \mathrm{g} \mathrm{L}^{-1}$. The precision (RSD \%) for 10 replicate determinations at 40 and $80 \mu \mathrm{g} \mathrm{L}^{-1}$ concentration was 2.5 and $2.1 \%$, respectively. The sample throughput was $30 \mathrm{~h}^{-1}$ for a 5-mL sample. The effect of common interfering ions present in water samples on the selectivity of the resin towards zinc was also studied and the tolerance limit for them is reported. To test the accuracy of the developed online FI-FAAS procedure, standard reference material (SRM) NIST 1643e Trace Elements in Water was analyzed. Further-more, the developed procedure was successfully tested for spiked water samples.

\section{INTRODUCTION}

Zinc is an essential trace metal ion for humans and plays a crucial role in various metabolic and environmental processes. It is an essential part of more than 200 enzymes involved in biochemical activities as diverse as digestion, metabolism, reproduction, cell replication, protein synthesis and gene expression. Furthermore, the biological functions of zinc, which are versatile and observed in many tissues, are

*Corresponding autbor.

:E-mail: reenasax@botmail.com most often associated with proteins (1). It is also used for galvanization of steel and iron and in dry batteries, photoengraving, and lithography (2). It is of major importance in various commercial fields such as wastewater control, metallurgy, alloy manufacturing, agriculture (fertilizers and soil analysis), and pharmaceuticals (3). The permissible limit for zinc in drinking water as recommended by WHO is $5 \mathrm{mg} \mathrm{L}^{-1}$ (4). Zinc deficiency is closely associated with neurological diseases such as Alzheimer's and Parkinson's disease, Epilepsy, and also impairs the immune system (5). On the other hand, if present in excess, it accelerates oxidative damage in the human body which leads to premature ageing (6). Therefore, the development of a selective, sensitive, and swift method to monitor zinc ion concentrations in water samples is required.

Many methods have been employed for zinc determination such as spectrophotometry $(7,8)$, flame atomic absorption spectrometry (FAAS) $(9,10)$, electrothermal atomic absorption spectrometry (ETAAS) (11), graphite furnace atomic absorption spectrometry (12), inductively coupled plasma mass spectrometry (ICP-MS) $(13,14)$, and X-ray fluorescence spectrometry (15). The methods mentioned above are highly sensitive and accurate. However, certain disadvantages such as high cost, loss of analyte, use of toxic reagents, and prolonged operational time limits their use. For this, on-line solid phase extraction (SPE) (16) has shown great promise and become one of the most active research fields in automated solution analysis in recent years because of its advantages, such as high preconcentration factor, high recovery, low cost, low consumption of organic solvents, and the ability to couple with different detection techniques. On-line column preconcentration is based on the incorporation of minicolumns packed with various sorbent materials (17). The selection of a sorbent is an important step in SPE as it controls analytical parameters such as selectivity, affinity, and capacity (18). The materials which have been used as sorbents for on- 
line preconcentration of metal ions are silica gel modified with niobium(V) oxide (19), divinylbenzene functionalized with 1-(2-pyridylazo) 2-naphtol (PSDVB-PAN) (20), oamino benzoic acid functionalized with Amberlite XAD-4 (21), chitosan resin functionalized with 2-amino-5-hydroxy benzoic acid and 8-hydroxyquinoline $(22,23)$, 3,4-dihydroxybenzoic acid functionalized with Amberlite ${ }^{\circledR}$ XAD-4 (24), Xylenol orange functionalized with Amberlite XAD-2 $(25,26)$, and salicylic acid functionalized with Amberlite XAD-2 (27). Chelating ions have a triple function: ion exchange, chelate formation, and physical adsorption which makes them a better choice for the preconcentration of metal ions over solvent extraction and ion exchange (28). The functional groups responsible for chelation usually include oxygen, nitrogen, and sulfur atoms. The selectivity and sorption capacity of a chelating resin can be affected by factors such as chemical activity of the chelating group, nature of the metal ions, $\mathrm{pH}$ of the solution, ionic strength, and nature of the sorbent material (29).

In the present work, the chelating resin 8-hydroxyquinoline (oxine) loaded onto Amberlite XAD-2 was synthesized and used for the first time in an on-line flow injection column preconcentration system for the determination of zinc. All analytical parameters such as $\mathrm{pH}$, concentration of eluent, sample and eluent flow rates, and also the effect of matrix components and interfering ions were studied and are described.

\section{EXPERIMENTAL}

\section{Instrumentation}

A PerkinElmer ${ }^{\circledR}$ (Shelton, CT, USA) AAnalyst ${ }^{\mathrm{TM}} 400$ flame atomic absorption spectrometer, coupled with the FIAS ${ }^{\text {TM }} 400$ flow injection system (Figure 1), was used for the automatic processing of the method and operated in the preconcentration mode. The instrumental parameters are listed in Table I. The whole system was controlled by a personal computer and WinLab32 ${ }^{\mathrm{TM}}$ (Version 6.5.0.0266) application software. The FIAS 400 preconcentration system is equipped with two peristaltic pumps, two positional valves, and a preconcentration column. Tygon ${ }^{\circledR}$ R3607 tubes (i.d. $1.14 \mathrm{~mm}$ ) were used for both pumps in most of the experiments. The $\mathrm{pH}$ measurements were made with a Model LI614 pH meter (Elico Ltd., India). An IR spectrum was recorded on a PerkinElmer Spectrum RX-1. CHNS was carried out on a Model Vario EL-III Elementor (Elementar

\section{Atomic Apectroscopy \\ 1 Vol. 35(4), July/August 2014}

Analysensysteme GmbH, Germany). Thermal analysis was performed with a PerkinElmer Diamond DSC. Scanning electron microscopy (SEM) was carried out using the Scanning Electron Microscope FEI Quanta 200F (ICON, The Netherlands).

\section{Standard Solutions and Reagents}

A $1000 \mathrm{mg} \mathrm{L}^{-1}$ stock solution of zinc was prepared from analytical reagent grade $\mathrm{Zn}$ (II) nitrate in doubly distilled water obtained from a double distillation unit (Double Distillation Water Unit, WDU-2000, Quartz H, Mohindra Glass Industries, New Delhi, Delhi) and stan-

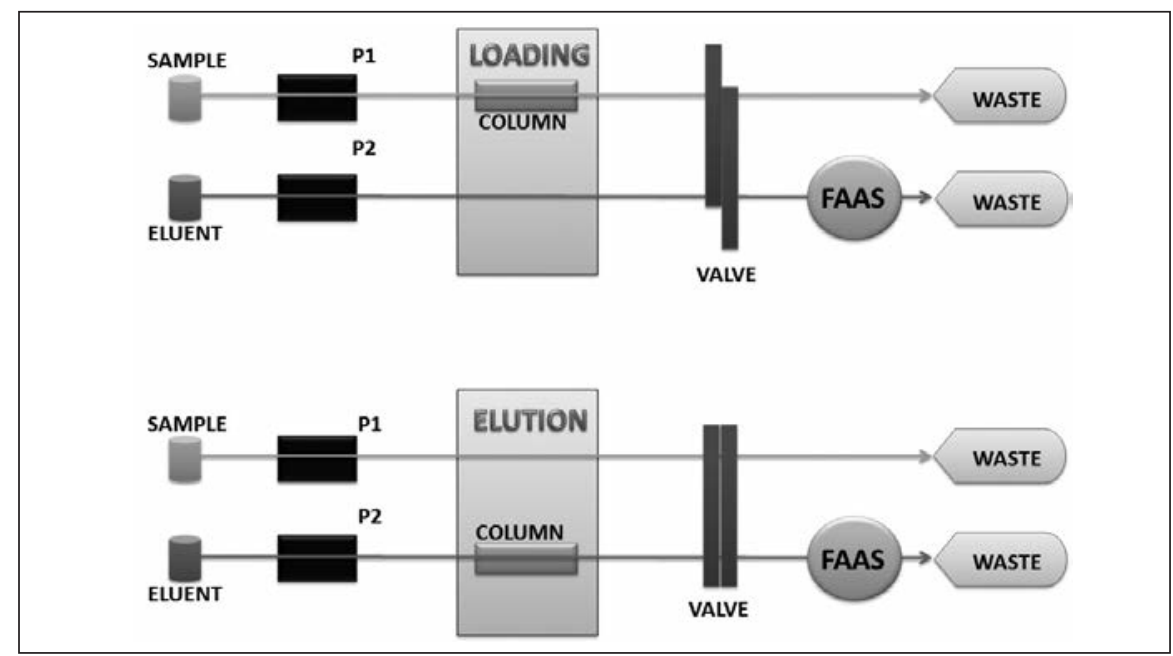

Fig. 1. Flow injection preconcentration system using the PerkinElmer FIAS 400.

TABLE I

AAnalyst Flame AAS 400 Instrumental Operating Parameters

\begin{tabular}{ll}
\hline Recommended Conditions & Zinc \\
\hline Wavelength & $213.86 \mathrm{~nm}$ \\
Slit Width & $2.7 / 1.8 \mathrm{~mm}$ \\
Lamp Current & $25 \mathrm{~mA}$ \\
Relative Noise & 1 \\
Characteristic Conc. & $0.006 \mathrm{mg} / \mathrm{L}$ \\
Sensitivity Check & $0.3 \mathrm{mg} / \mathrm{L}$ \\
Linearity & $0.75 \mathrm{mg} / \mathrm{L}$ \\
Oxidant & Air \\
Oxidant Flow & $10.0 \mathrm{~L} / \mathrm{min}$ \\
Acetylene Flow Rate & $2.5 \mathrm{~L} / \mathrm{min}$ \\
WinLab32 & Version 6.5 .0 .0266 \\
\hline
\end{tabular}


dardized titrimetically with ethylenediaminetetraacetic acid (EDTA) before use. Standard solutions were prepared by dilution of the stock solutions with doubly distilled water. The $\mathrm{pH}$ adjustments were made with $0.1 \mathrm{M} \mathrm{HCl}, 0.1 \mathrm{M} \mathrm{NaOH}$. All laboratory glassware was kept overnight in a $10 \%(\mathrm{v} / \mathrm{v})$ nitric acid solution and washed before use with doubly distilled water. Amberlite XAD-2 resin (Sigma Aldrich, USA) has a surface area of approximately $300 \mathrm{~m}^{2} / \mathrm{g}$, a moisture holding capacity of $54-60 \%$, particle size of 20-60 mesh, pore diameter of $90 \AA$ (mean pore size), and a pore volume of $0.65 \mathrm{~mL} / \mathrm{g}$.

The 8-hydroxyquinoline (E. Merck) used was of analytical reagent grade. All analytical reagents were procured from either E. Merck (Darmstadt, Germany) or Thomas Baker (India). Certified Zn(II) nitrate solution, traceable to NIST, was procured from E. Merck. The standard reference material (SRM) NIST 1643e Trace Elements in Water was obtained from the National Institute of Standards and Technology, Gaithersburg, MD, USA.

\section{Real Water Samples}

The water samples were collected from three different places: Noida (U.P), Narayana, and Mayapuri, Delhi, India. These places were near industries where galvanization of steel is taking place. The samples were stored in polyethylene bottles and after pretreatment with nitric acid, they were immediately placed in the refrigerator until analysis.

Synthesis of Amberlite XAD-2 Functionalized with 8-Hydroxyquinoline (AXAD2-HQ)

Chelating Resin

Amberlite ${ }^{\circledR}$ XAD-2 (styrenedivinylbenzene copolymer) was modified according to the procedure reported in the literature (19). Synthesis involves nitration of
$5.0 \mathrm{~g}$ of Amberlite XAD-2 with a nitrating mixture of $10 \mathrm{~mL}$ of concentrated $\mathrm{HNO}_{3}$ and $25 \mathrm{~mL}$ of concentrated $\mathrm{H}_{2} \mathrm{SO}_{4}$ placed in a round bottom flask. This solution was then put on a hot plate at $60^{\circ} \mathrm{C}$ for 30 minutes and mixed with a magnetic stirrer. The nitrated resin was filtered, repeatedly washed with doubly distilled water until free from acid, then reduced to form an aromatic amine by using $40 \mathrm{~g}$ of $\mathrm{SnCl}_{2}, 45 \mathrm{~mL}$ of concentrated $\mathrm{HCl}$, $50 \mathrm{~mL}$ of ethanol, and refluxing for 10 hours at $90{ }^{\circ} \mathrm{C}$. This amine facilitates the formation of a stable diazonium salt. The diazotized resin was filtered, washed with cold doubly distilled water, and reacted with hydroxyquinoline at $0-3{ }^{\circ} \mathrm{C}$ for 24 hours. The resulting brown-colored beads were filtered, washed with doubly distilled water, and airdried. The structure of AXAD2-HQ resin is shown in Figure 2.

\section{Fabrication of Mini-column}

The newly synthesized AXAD2HQ resin ( $150 \mathrm{mg})$ was packed in a fabricated mini-glass column (3.0 cm length and $3.0 \mathrm{~mm}$ i.d.). The mini-column was treated with $2.0 \mathrm{~mol} \mathrm{~L}^{-1} \mathrm{HNO}_{3}$ and washed with doubly distilled water until the

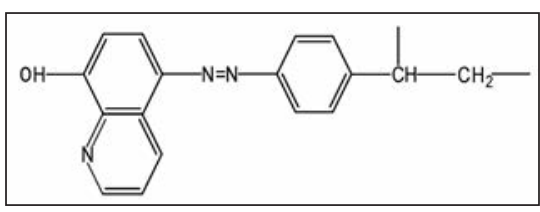

Fig. 2. Proposed structure of Amberlite XAD-2 functionalized with 8-bydroxyquinoline resin. resin was free from acid. The two ends of the column were sealed with cotton. A suitable volume of the solution containing zinc $(5 \mathrm{~mL})$ in the concentration range of $0-80 \mu \mathrm{g} \mathrm{L}^{-1}$ was passed through this column after adjusting its $\mathrm{pH}$ to an optimum value. The column continually performed during all experiments and there was no need for any regeneration or repacking.

\section{Precocentration Procedure Using the FIAS 400 Flow Injection System}

The flow injection (FI) FAAS analysis program was controlled by a computer program (Table II) which includes the pre-filling, filling, loading and elution steps (21). The preconcentration and determination of zinc was carried out using two peristaltic pumps fitted with Tygon ${ }^{\circledR}$ tubes, a three-way rotary valve, and a mini-column packed with AXAD2-HQ resin coupled to the FAAS. The flow system was operated in a time-based mode. A 5-mL sample solution containing $50 \mu \mathrm{g} \mathrm{L}^{-1}$ of zinc(II) ions was buffered at $\mathrm{pH}$ 8.0, pumped at $5.0 \mathrm{~mL} \mathrm{~min}^{-1}$, and then passed through a mini-column that retains the $\mathrm{Zn}$ (II) ions. The elution was carried out using $\mathrm{HNO}_{3}$ at an optimum

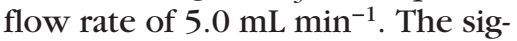
nals were recorded as absorbance using the instrument software. The sampling rate achieved was 30 samples per hour for a preconcentration time of 60 seconds and an elution time of 30 seconds.
TABLE II

Online Flow Injection Program for the Preconcentration of Trace Metal Ions

\begin{tabular}{lcccccc}
\hline Step & Time(s) & Pump 1 & Pump 2 & Loading & Elution & Reading \\
\hline Pre-fill & 1 & + & + & + & - & - \\
1 & 10 & + & - & + & - & - \\
2 & 20 & - & + & + & + & - \\
3 & 50 & + & + & + & - & - \\
4 & 10 & + & + & + & + \\
5 & 30 & - & + & + & + \\
\hline
\end{tabular}




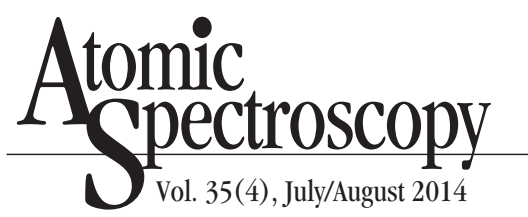

\section{RESULTS AND DISCUSSION}

\section{Characterization of Amberlite XAD-2 Functionalized With 8-Hydroxyquinoline (AXAD2- HQ) Chelating Resin}

\section{FT-IR Spectrum}

The chelating resin shows bands (Figure 3) of Amberlite XAD-2 and the chelating agent 8-hydroxyquinoline is loaded onto the resin. The AXAD2-HQ resin has bands at $3421 \mathrm{~cm}^{-1}$ (O-H stretching), 2924 $\mathrm{cm}^{-1}$ (C-H stretching), $1615 \mathrm{~cm}^{-1}$ $(\mathrm{C}=\mathrm{N}), 1346 \mathrm{~cm}^{-1}(\mathrm{C}-\mathrm{N}), 1109 \mathrm{~cm}^{-1}$ (C-O), and $1515 \mathrm{~cm}^{-1}(-\mathrm{N}=\mathrm{N}-)$, which did not appear in the IR spectrum of the Amberlite XAD-2 except the $\mathrm{C}-\mathrm{H}$ stretching. This supports the fact that the 8-hydroxyquinoline is loaded onto Amberlite XAD2 by diazotized $(\mathrm{N}=\mathrm{N})$ coupling.

\section{Thermogravimetric Analysis} (TGA)

The thermogravimetric analysis (TGA) curve of freshly prepared AXAD2-HQ resin showed a very slow but steady weight loss up to $600{ }^{\circ} \mathrm{C}$. The observed weight loss was $6.9 \%$ up to $120{ }^{\circ} \mathrm{C}$. This is due to physisorbed water on the resin, which showed the presence of only one water molecule per repeat unit of chelating resin. It can be assumed that with each ring one dye molecule is covalently bonded to an azo group and occupies a para position to the $-\mathrm{CH}-\mathrm{CH}_{2}$ - group.

\section{CHN Elemental Analysis}

The CHN elemental analysis provides a mean for the rapid determination of carbon, hydrogen, and nitrogen in organic matrices. The $\mathrm{C}, \mathrm{H}$, and $\mathrm{N} \%$ in AXAD2-HQ resin was found to be $\mathrm{C}=70.42 \%$, $\mathrm{H}=4.86 \%, \mathrm{~N}=15.02 \%$, while calculated for $\mathrm{C}_{17} \mathrm{H}_{14} \mathrm{~N}_{3} \mathrm{O} \cdot 1 \mathrm{H}_{2} \mathrm{O}$ it was $\mathrm{C}=69.38 \%, \mathrm{H}=4.76 \%, \mathrm{~N}=14.28 \%$. It further confirmed that one water molecule per repeat unit of chelating resin was formed.

\section{SEM}

A scanning electron microscope (SEM) is a type of electron microscope that produces images of a sample by scanning it with a focused beam of electrons (30). The electrons interact with electrons in the sample, producing

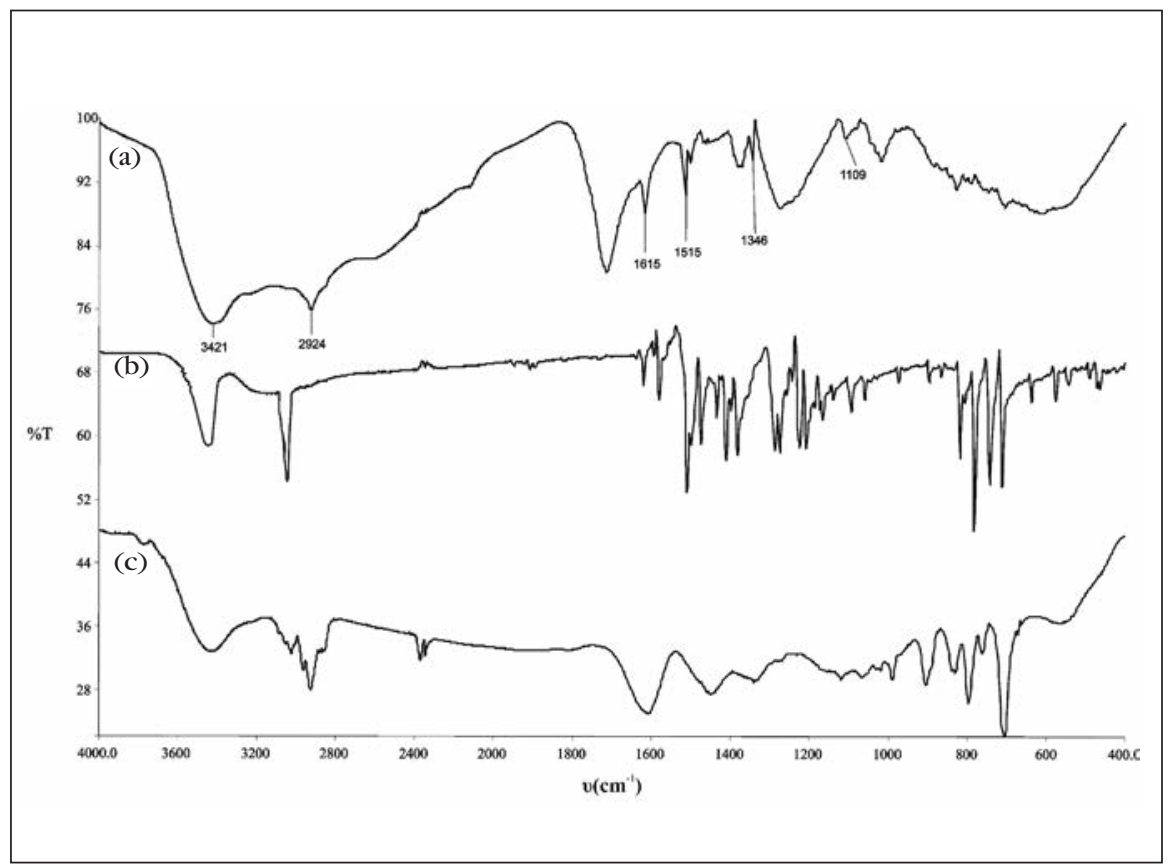

Fig. 3. Infrared spectra of Amberlite XAD-2 functionalized with 8-bydroxyquinoline resin: (a) $A X A D 2-H Q$ resin, (b) 8-hydroxyquinoline, (c) Amberlite XAD-2.

various signals that can be detected and that contain information about the sample's surface topography and composition. The micrographs (Figures $4 \mathrm{a}$ and $4 \mathrm{~b}$ ) show that the pure resin has a smooth and flat surface, while the modified chelating resin shows dense microstructures and granular grains. This shows that the ligand loads onto the support. The substrate surface was changed after functionalization with 8-hydroxyquinoline. The newly synthesized AXAD2-HQ resins are agglomerated polymeric materials with irregular shapes and sizes and vary from 30 to $500 \mu \mathrm{m}$.

\section{Optimization of Flow Injection Variables}

In order to improve the performance characteristics of the method, both chemical and flow variables were thoroughly studied for $\mathrm{Zn}$ (II). A standard solution of $50.0 \mu \mathrm{g} \mathrm{L}^{-1} \mathrm{Zn}$ (II) with a 60-second preconcentration time for all major variables such as sample $\mathrm{pH}$, eluent, sample, and eluent flow rate was analyzed using FI-FAAS.

The effect of $\mathrm{pH}$ (ranging from 2.0-10.0) on samples containing $\mathrm{Zn}$ (II) ions was examined. The results show that the $\mathrm{Zn}$ (II) ions were quantitatively adsorbed at pH 8.0 (Figure 5). The low absorbance of $\mathrm{Zn}$ (II) at high acidity was due to the low complex formation rather than the low retention efficiency of the packing material. In order to obtain the best conditions for the determination after preconcentration, the $\mathrm{pH} 8.0$ was chosen.

Elution studies were performed in order to obtain maximum recovery with minimal concentration and volume of elution solution. For desorbing metal ions already adsorbed on the adsorbent, different concentrations of the eluent ranging from 0.01-2.0 $\mathrm{mol} \mathrm{L}^{-1} \mathrm{HNO}_{3}$ were examined. The results show that with an increase in the $\mathrm{HNO}_{3}$ concentration 
up to $0.3 \mathrm{~mol} \mathrm{~L}^{-1}$, the absorbance increases, then decreases at higher concentrations (see Figure 6). Thus, $0.3 \mathrm{~mol} \mathrm{~L}^{-1} \mathrm{HNO}_{3}$ was selected for the quantitative recovery of the $\mathrm{Zn}$ (II).

The influence of eluent flow rate in the elution step was studied within the range of $2.0-7.0 \mathrm{~mL} \mathrm{~min}^{-1}$ because it establishes the velocity of the acid solution through the mini-column. The results obtained showed that the analytical signal is maximum at an eluent flow rate of $5.0 \mathrm{~mL} \mathrm{~min}^{-1}$ (Figure 7). Moreover, higher flow rates increase back pressure which could cause leakage from the column. The elution time was fixed at 30 seconds in order to ensure the complete elution of adsorbed $\mathrm{Zn}$ (II) ions even at high concentrations.

The flow rate of the sample solution through the column not only affects the recovery of the analyte but also controls the time of the analysis. The effect of sample flow rate on the preconcentration of $50 \mu \mathrm{g} \mathrm{L}^{-1} \mathrm{Zn}$ (II) for a 60 -second loading time under $\mathrm{pH} 8.0$ was studied in the range of $2.0-7.0 \mathrm{~mL}$ $\mathrm{min}^{-1}$. Quantitative recovery of the $\mathrm{Zn}$ (II) ion was obtained with a flow rate of $5.0 \mathrm{~mL} \mathrm{~min}{ }^{-1}$. At higher flow rates, back pressure is produced by the mini-column. Low flow rates decrease the sample throughput and results in a long analysis time. In order to improve the analytical efficiency, $5.0 \mathrm{~mL} \mathrm{~min}^{-1}$ was chosen as the loading rate for $\mathrm{Zn}$ (II) ions (Figure 8).

\section{Analytical Performance of the On-line Preconcentration Sys- tem for $\mathrm{Zn}$ (II) Determination}

The characteristic data under the optimum chemical and flow conditions, including the regression equation before and after the preconcentration method for the online preconcentration system for $\mathrm{Zn}$ (II) with AXAD2-HQ resin, are listed in Table III. The enhance-
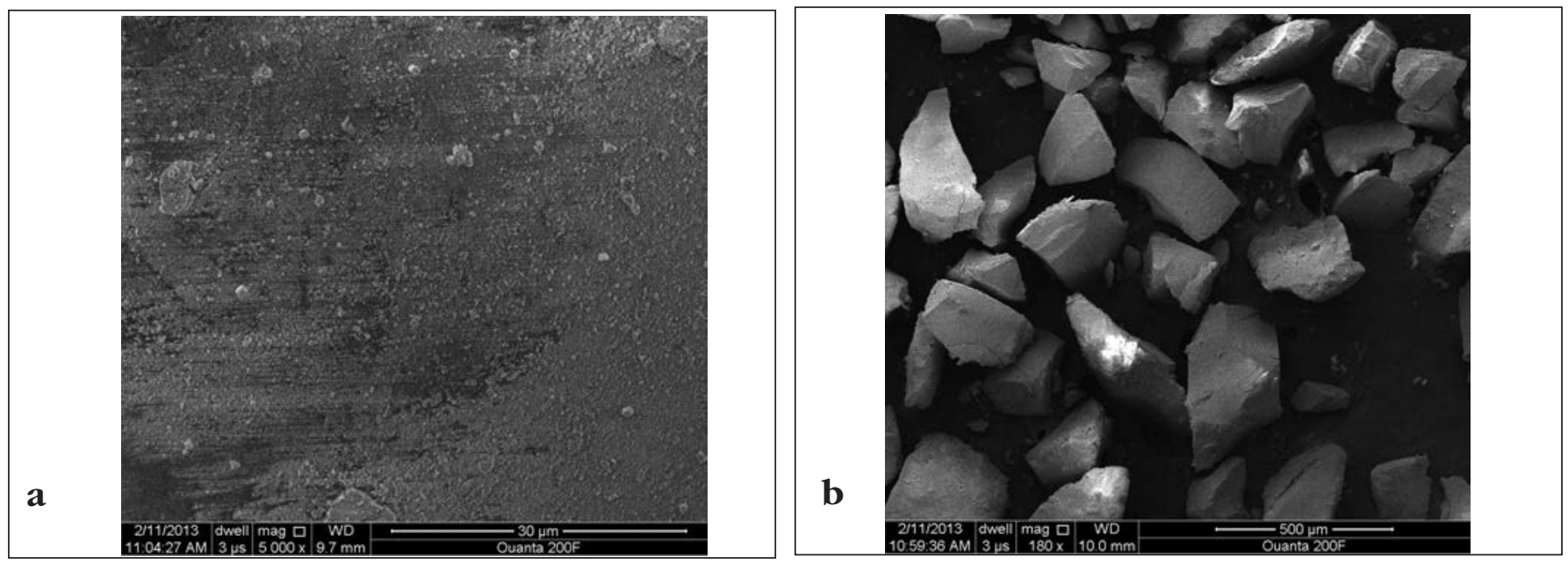

Fig. 4 ( $a$ and b). SEM images: (a) Amberlite XAD-2, (b) Amberlite XAD2-HQ resin.

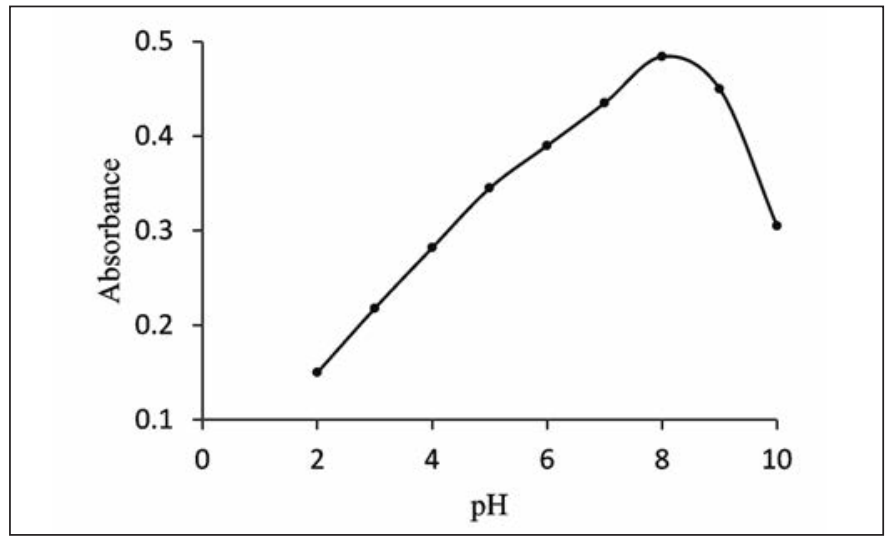

Fig. 5. Effect of $p H$ on the absorbance.

Conditions: Preconcentration of $5 \mathrm{~mL}$ of $50 \mu \mathrm{g} \mathrm{L} \mathrm{L}^{-1} \mathrm{Zn}$ (II) with flow rate of $5 \mathrm{~mL} \mathrm{~min}^{-1}$ and elution with $0.3 \mathrm{~mol} \mathrm{~L}^{-1} \mathrm{HNO}_{3}$ at flow rate of $5 \mathrm{~mL} \mathrm{~min}^{-1}$.

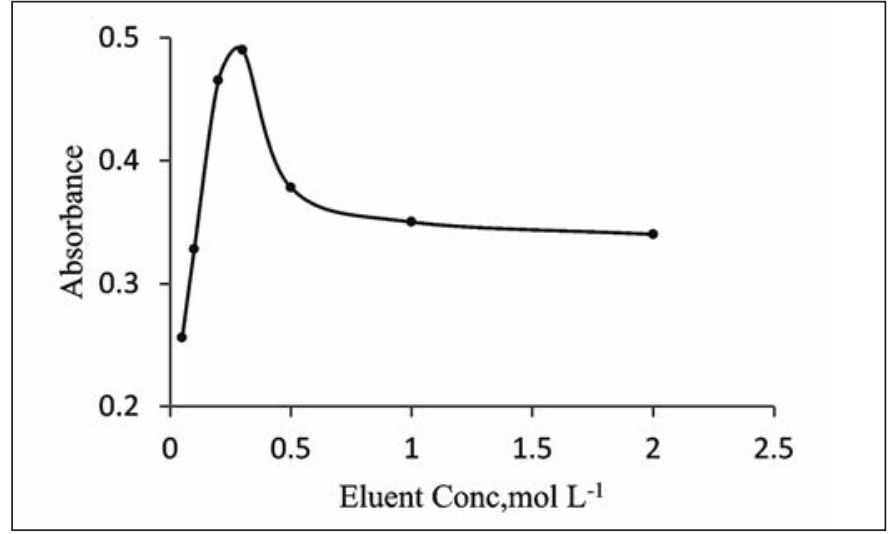

Fig. 6. Effect of eluent concentration on the absorbance. Conditions: Preconcentration of $5 \mathrm{~mL}$ of $50 \mu \mathrm{g} \mathrm{L} \mathrm{L}^{-1} \mathrm{Zn}(\mathrm{II})$ buffered at $\mathrm{pH} 8.0$ and elution with $\mathrm{HNO}_{3}$ at flow rate of $5 \mathrm{~mL} \mathrm{~min}^{-1}$. 


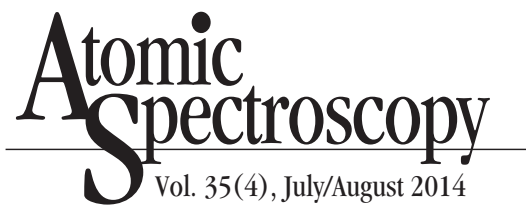

ment factor (EF) was based on the ratio of the slopes of the calibration curves, obtained with and without preconcentration, using FAAS. It was observed that the detection limits and the enrichment factors will increase with a longer preconcentration time. The calibration graphs were linear at a preconcentration time of 60, 120, and 180 seconds. By using $\mathrm{pH} 8.0$ and

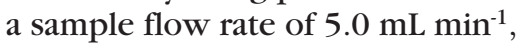
the enhancement factors obtained were 28,68 , and 137 , respectively. The detection limits (DL) were found to be $1.38,1.092$, and $0.33 \mu \mathrm{g} \mathrm{L}^{-1}$, respectively. The precision (RSD) of $2.5 \%$ and $2.1 \%$ was obtained at 40 and $80 \mu \mathrm{g} \mathrm{L} \mathrm{L}^{-1} \mathrm{Zn}$ (II), respectively. The sample throughput of $30 \mathrm{~h}^{-1}$ was obtained at a 60-second preconcentration time. A lower sample throughput of 20 and $15 \mathrm{~h}^{-1}$ was obtained by using longer preconcentration times of 120 and 180 seconds. Higher preconcentration times could be beneficial for the determination of samples with lower $\mathrm{Zn}$ (II) concentrations. However, long time periods are not suitable for flow injection preconcentration systems as sample throughput is low.

Hence, a preconcentration time of 60 seconds was used for the determination of $\mathrm{Zn}$ (II) in water samples.
TABLE III

Analytical Features of the On-line Zn(II) Preconcentration System Using AXAD2- HQ Resin

\begin{tabular}{|c|c|c|c|}
\hline Parameters & \multicolumn{3}{|c|}{ Optimum Conditions } \\
\hline $\mathrm{pH}$ & \multicolumn{3}{|l|}{8.0} \\
\hline Sample Flow Rate & \multicolumn{3}{|c|}{$5.0 \mathrm{~mL} \mathrm{~min}^{-1}$} \\
\hline Eluent Flow Rate & \multicolumn{3}{|c|}{$5.0 \mathrm{~mL} \mathrm{~min}^{-1}$} \\
\hline Acid Conc. for Desorption & \multicolumn{3}{|c|}{$0.3 \mathrm{~mol} \mathrm{~L}^{-1} \mathrm{HNO}_{3}$} \\
\hline Preconcentration Time & $60 \mathrm{~s}$ & $120 \mathrm{~s}$ & $180 \mathrm{~s}$ \\
\hline Linear Range $\left(\mu \mathrm{g} \mathrm{L}^{-1}\right)$ & $0-80$ & $0-35$ & $0-22$ \\
\hline Limit of Detection $\left(\mu \mathrm{g} \mathrm{L}^{-1}\right)$ & 1.38 & 1.092 & 0.33 \\
\hline Sample Throughput $\left(\mathrm{h}^{-1}\right)$ & 30 & 20 & 15 \\
\hline Enhancement Factor & 28 & 68 & 137 \\
\hline Regression Equation & \multicolumn{3}{|c|}{$\mathrm{A} 60=0.00923+0.00841 \quad[\mathrm{Zn}(\mathrm{II})]$} \\
\hline $\begin{array}{l}\text { ( } 6 \text { Standards, } \mathrm{Zn}(\mathrm{II}) / \mu \mathrm{g} \mathrm{L} \mathrm{L}^{-1} \text { ) } \\
\text { (with preconcentration) }\end{array}$ & \multicolumn{3}{|c|}{$\begin{array}{l}\mathrm{A} 120=-0.01018+0.02112[\mathrm{Zn}(\mathrm{II})] \\
\mathrm{A} 180=0.00264+0.04283[\mathrm{Zn}(\mathrm{II})]\end{array}$} \\
\hline \multicolumn{4}{|l|}{ Regression Equation } \\
\hline $\begin{array}{l}\text { ( } 6 \text { Standards, } \mathrm{Zn}(\mathrm{II}) / \mu \mathrm{g} \mathrm{L}^{-1} \text { ) } \\
\text { (without preconcentration) }\end{array}$ & \multicolumn{3}{|c|}{$\mathrm{A}=0.02056+0.00031252[\mathrm{Zn}(\mathrm{II})]$} \\
\hline Correlation Coefficient (r) & 0.994262 & 0.999553 & 0.995232 \\
\hline \multirow[t]{2}{*}{ Precision (\%) } & \multicolumn{3}{|c|}{$2.5,[\mathrm{Zn}(\mathrm{II})]=40 \mu \mathrm{g} \mathrm{L}^{-1}$} \\
\hline & \multicolumn{3}{|c|}{$2.1,[\mathrm{Zn}(\mathrm{II})]=80 \mu \mathrm{g} \mathrm{L}^{-1}$} \\
\hline
\end{tabular}

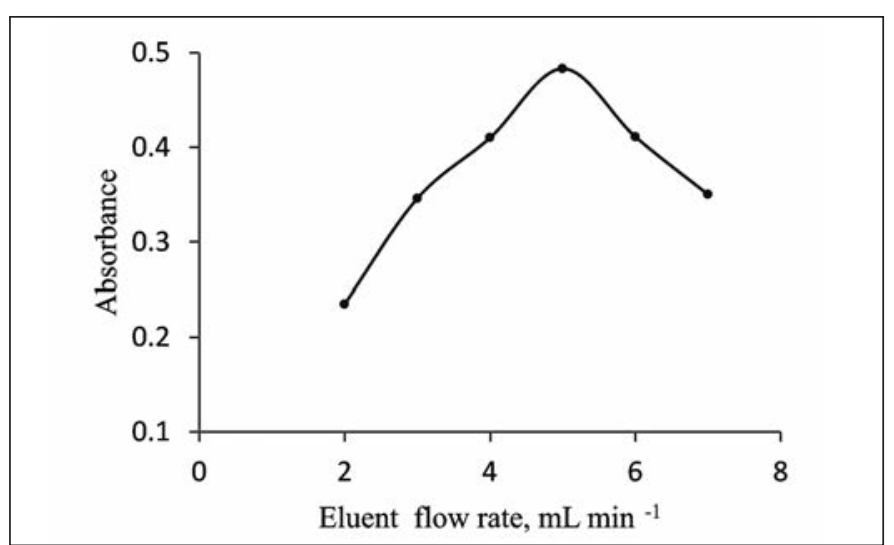

Fig. 7. Effect of eluent flow rate on the absorbance. Conditions: Preconcentration of $5 \mathrm{~mL}$ of $50 \mu \mathrm{g} \mathrm{L} \mathrm{L}^{-1} \mathrm{Zn}$ (II)

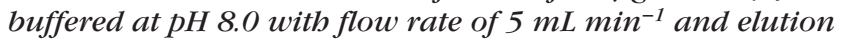
with $0.3 \mathrm{~mol} \mathrm{~L}^{-1} \mathrm{HNO}_{3}$.

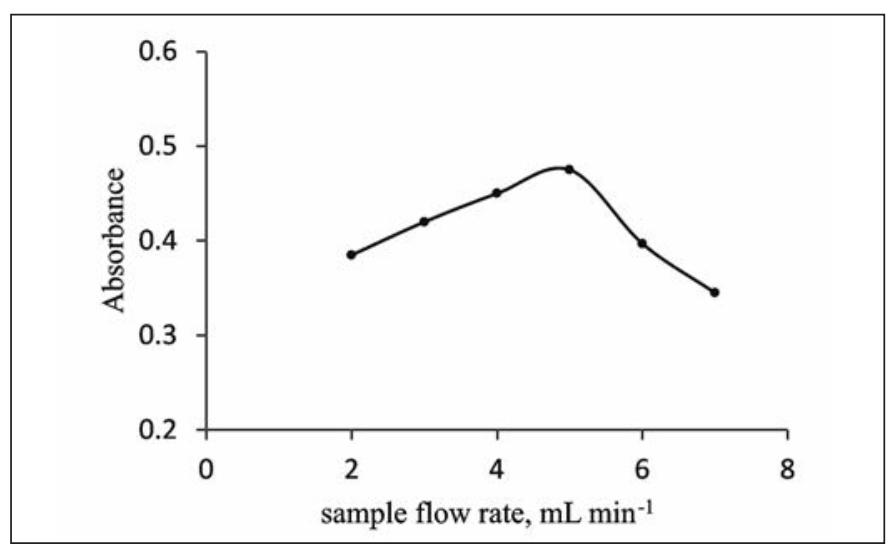

Fig. 8. Effect of sample flow rate.

Conditions: Preconcentration of $5 \mathrm{~mL}$ of $50 \mu \mathrm{g} \mathrm{L}^{-1} \mathrm{Zn}$ (II), buffered at $\mathrm{pH} 8.0$, and elution with $0.3 \mathrm{~mol} \mathrm{~L}^{-1} \mathrm{HNO}_{3}$ at flow rate of $5 \mathrm{~mL} \mathrm{~min}^{-1}$. 


\section{Interference Studies}

Application of the proposed preconcentration method for the determination of $\mathrm{Zn}$ (II) ions in samples with a complicated matrix was also investigated such as the influences of some alkali, alkaline earth, and transition metal ions on the recovery of $\mathrm{Zn}$ (II). Chloride, nitrate, and sulfate ions commonly found in natural water samples have the capability to complex with many metal ions (31). Therefore, in their presence, the efficiency of the chelating resins to bind metal ions may be hampered resulting in the reduction of the overall enrichment. Thus, the effect of $\mathrm{Na}^{+}, \mathrm{Cl}^{-}, \mathrm{NO}_{3}{ }^{-}, \mathrm{SO}_{4}{ }^{2-}, \mathrm{Br}^{-}$, $\mathrm{Mg}^{2+}, \mathrm{Pb}^{2+}, \mathrm{Cd}^{2+}, \mathrm{Cu}^{2+}, \mathrm{Ca}^{2+}, \mathrm{Al}^{3+}$, and $\mathrm{K}^{+}$on the sorption efficiency of AXAD2-HQ resin for $50 \mu \mathrm{g} \mathrm{L}^{-1}$ $\mathrm{Zn}$ (II) was studied using the recommended flow injection column method under optimum conditions. The tolerance limits of several foreign substances in the preconcentration of $\mathrm{Zn}$ (II) are listed in Table IV. A species is considered to interfere when it lowers the recovery of the metal ions by more than $\pm 5 \%$. The results in Table IV demonstrate that the presence of large amounts of these metal ions in the sample have no significant effect on the analytical signal of $\mathrm{Zn}$ (II).

TABLE IV

Effects of Matrix Ions on the Recovery of $\mathrm{Zn}$ (II)

\begin{tabular}{lc}
\hline Interfering Ion & $\begin{array}{c}\text { Tolerance Limit } \\
\left(\mathrm{mg} \mathrm{L}^{-1}\right)\end{array}$ \\
\hline $\mathrm{Na}^{+}$ & 40,000 \\
$\mathrm{Cl}^{-}$ & 18,000 \\
$\mathrm{Br}^{-}$ & 15,000 \\
$\mathrm{Mg}^{2+}$ & 8,000 \\
$\mathrm{SO}_{4}{ }^{2-}$ & 3,000 \\
$\mathrm{NO}_{3}{ }^{-}$ & 2,500 \\
$\mathrm{Cd}^{2+}$ & 25 \\
$\mathrm{~Pb}^{2+}$ & 18 \\
$\mathrm{Ca}^{2+}$ & 15 \\
$\mathrm{~K}^{+}$ & 12 \\
$\mathrm{Al}^{3+}$ & 10 \\
$\mathrm{Cu}^{2+}$ & 10 \\
\hline
\end{tabular}

\section{Analytical Application for Water} Samples

The proposed method was applied for the analysis of tap water samples and validated by spiking the samples with known amounts of certified $\mathrm{Zn}$ (II) nitrate solution, traceable to NIST. These water samples were collected from three different places: Noida (U.P.), Narayana, and Mayapuri, Delhi, India. These places are near industries where galvanization of steel takes place. For these samples, the only pre-treatment performed was acidification to $\mathrm{pH} 2.0$ with nitric acid, which was done immediately after collection in order to prevent adsorption of the $\mathrm{Zn}$ (II) ions on the flask walls. The samples were stored in polyethylene bottles and immediately placed in a refrigerator until analysis. All water samples were filtered through a $0.45 \mu \mathrm{m}$ pore size membrane filter to remove suspended particulate matter. The filtrate was adjusted to $\mathrm{pH} 8$ by addition of a buffer solution and subjected to on-line
FI-FAAS determination using AXAD2-HQ resin as column material and following the procedure described above. The recoveries from the spiked samples ranged from $97-99 \%$. The analytical results along with the recoveries are summarized in Table V.

\section{Accuracy of On-line Preconcen- tration Method}

In order to evaluate the accuracy of the developed on-line preconcentration procedure, it was verified by the analysis of NIST SRM 1643e Trace Elements in Water (National Institute of Standards and Technology, Gaithersburg, MD, USA). The certified value of $78.5 \pm$ 2.2 for $\mathrm{Zn}$ (II) was used to verify the accuracy of the proposed methodology on total concentration determination. The concentration found was $76.8 \pm 2.6 \mu \mathrm{g} \mathrm{L}^{-1}$ which is in good agreement with the certified values listed in Table VI.

\section{TABLE V}

Analytical Results Obtained With FIAS-400 Flow Injection System for the Determination of $\mathrm{Zn}$ (II) in Real Water Samples

\begin{tabular}{|c|c|c|c|c|}
\hline Sample & \multicolumn{2}{|c|}{$\begin{array}{l}\text { Conc. } \\
\text { Determined } \\
\left(\mu \mathrm{g} \mathrm{L}^{-1}\right)\end{array}$} & $\begin{array}{l}\text { Conc. } \\
\text { Determined } \\
\text { by } 20 \mu \mathrm{g} \mathrm{L}^{-1} \\
\text { Spiked } \mathrm{Zn}(\mathrm{II}) \\
\quad\left(\mu \mathrm{g} \mathrm{L}^{-1}\right)\end{array}$ & $\begin{array}{l}\text { Recovery } \\
(\%)\end{array}$ \\
\hline $\begin{array}{l}\text { Noida, Industrial Area, } \\
\text { U.P., India }\end{array}$ & \multicolumn{2}{|c|}{$40.44 \pm 2.2$} & $59.39 \pm 2.1$ & $98.2 \%$ \\
\hline $\begin{array}{l}\text { Nariana, Industrial Area, } \\
\text { Delhi, India }\end{array}$ & \multicolumn{2}{|c|}{$46.59 \pm 2.5$} & $65.72 \pm 2.3$ & $98.6 \%$ \\
\hline $\begin{array}{l}\text { Mayapuri, Industrial Area, } \\
\text { Delhi, India }\end{array}$ & \multicolumn{2}{|c|}{$42.56 \pm 2.6$} & $60.70 \pm 2.7$ & $97.0 \%$ \\
\hline \multicolumn{5}{|c|}{$\begin{array}{l}\text { TABLE VI } \\
\text { SRM NIST T }\end{array}$} \\
\hline \multicolumn{5}{|c|}{$\mathrm{Zn}(\mathrm{II})$ Amount $\left(\mu \mathrm{g} \mathrm{L}^{-1}\right)$} \\
\hline Sample & & $\begin{array}{l}\text { Certified } \\
\text { Value }\end{array}$ & $\begin{array}{l}\text { Proposed } \\
\text { Method }\end{array}$ & $\begin{array}{l}\text { Recovery } \\
(\%)\end{array}$ \\
\hline SRM1643e, Trace Elements ir & Jater & $78.5 \pm 2.2$ & $76.8 \pm 2.6$ & 98.61 \\
\hline
\end{tabular}




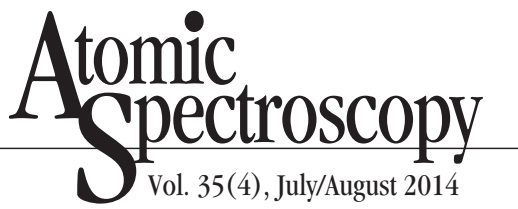

Comparison of Performance Characteristics of Newly Developed Chelating Resin With Other On-line SPE Methods

In Table VII, the figures of merit of the present and other selected on-line SPE preconcentration FAAS methods are summarized for comparative purposes. The proposed method shows good sensitivity (detection limit 0.33), better precision (2.1\% RSD,) and high sample throughput (30) with a very high enhancement factor (137-fold) over other on-line preconcentration methods.

\section{CONCLUSION}

The use of Amberlite XAD-2 modified with 8-hydroyquinoline as an adsorbent for the determination of $\mathrm{Zn}$ (II) in aqueous samples in an on-line FI-FAAS system was very efficient, resulting in excellent sensitivity and analytical frequency. The parameters including $\mathrm{pH}$ of the sample, sample volume, type and volume of eluents, and effect of foreign ions were studied. The principle interest in using this chelating resin for trace metal analysis is based on the simplicity of the method for the separation and preconcentration of the $\mathrm{Zn}$ (II) ions. Other advantages include low detection limit $\left(0.33 \mathrm{ug} \mathrm{L}^{-1}\right)$, high preconcentration factor (137-fold), short analysis time, and high selectivity. This proposed online system has high tolerance to interferences from matrix ions and thus allows the determination of $\mathrm{Zn}$ in a large range of samples. The sorbed ions can readily be desorbed with common mineral acids, resulting in a recovery of $\sim 98 \%$ in real water samples and the certified material.
TABLE VII

Comparison of Performance Characteristics Among Selected On-line SPE Methods and the Developed Method for the Zn(II) Determination with FAAS

\begin{tabular}{|c|c|c|c|c|c|c|c|}
\hline Support & Chelating Agent & Eluent & $\begin{array}{l}\text { PT } \\
(\mathrm{s})\end{array}$ & $\begin{array}{c}\text { RSD } \\
(\%)\end{array}$ & $\begin{array}{c}\mathrm{DL} \\
\left(\mu \mathrm{g} \mathrm{L}^{-1}\right)\end{array}$ & $\mathrm{EF}$ & Ref \\
\hline $\begin{array}{l}\text { Activated } \\
\text { carbon }\end{array}$ & - & $\mathrm{HNO}_{3}$ & - & 0.82 & 1.9 & 10.9 & $(32)$ \\
\hline Alumina & Alizarin Red S & $\mathrm{HNO}_{3}$ & 300 & 3.0 & 0.2 & 144 & (33) \\
\hline $\begin{array}{l}\text { Amberlite } \\
\text { XAD-4 }\end{array}$ & $\begin{array}{l}\text { 3,4-dihydroxybenzoic } \\
\text { acid }\end{array}$ & $\mathrm{HCl}$ & 60 & 2.1 & 2.3 & 54 & (10) \\
\hline $\begin{array}{l}\text { Amberlite } \\
\text { XAD-4 }\end{array}$ & $\begin{array}{l}\text { 2,6-dihydroxyphenyl- } \\
\text { diazoaminoazobenzene }\end{array}$ & $\mathrm{HCl}$ & 60 & 2.7 & 0.2 & 31 & (34) \\
\hline $\begin{array}{l}\text { Amberlite } \\
\text { XAD-16 }\end{array}$ & $\begin{array}{l}\text { 3-((2,6-dichlorophenyl) } \\
\text { (1H-indol-3-yl)methyl)- } \\
\text { 1H-indole (DCPIMI) }\end{array}$ & $\mathrm{HNO}_{3}$ & - & 2.3 & 1.5 & 225 & (35) \\
\hline - & $\begin{array}{l}\text { (2-pyridylazo) } \\
\text { resorcinol (PAR) }\end{array}$ & $\begin{array}{l}\text { oxalic } \\
\text { acid }\end{array}$ & 300 & 3.55 & 0.42 & - & (36) \\
\hline Micelle & $\begin{array}{l}\text { HBDAP(N,N/-bis } \\
\text { (2-hydroxy-5-bromo- } \\
\text { benzyl)1,2-diamino- } \\
\text { propane) }\end{array}$ & $\mathrm{HNO}_{3}$ & 60 & - & 0.89 & 8.4 & $(37)$ \\
\hline $\begin{array}{l}\text { PTFE } \\
\text { turnings }\end{array}$ & $\begin{array}{l}\text { Ammonium } \\
\text { pyrrolidine dithio- } \\
\text { carbamate }\end{array}$ & IBMK & 30 & 3.2 & 0.3 & 65 & (38) \\
\hline $\begin{array}{l}\text { Styrene- } \\
\text { Divinyl- } \\
\text { benzene }\end{array}$ & $\begin{array}{l}\text { 2-[hydroxy-bis } \\
\text { (4vinylphenyl) } \\
\text { methyl]pyrrolidine- } \\
\text { 1-carboxylic acid ethyl } \\
\text { esther }\end{array}$ & $\mathrm{HCl}$ & 2400 & 6.5 & 0.98 & - & (39) \\
\hline $\begin{array}{l}\text { Amberlite } \\
\text { XAD-2 }\end{array}$ & 8-hydroxyquinoline & $\mathrm{HNO}_{3}$ & 180 & 2.1 & 0.33 & 137 & $\begin{array}{l}\text { This } \\
\text { Work }\end{array}$ \\
\hline
\end{tabular}

PT: Preconcentration time; RSD: precision (relative standard deviation);

DL: detection limit; EF: enhancement factor.

\section{ACKNOWLEDGMENT}

The authors are thankful to the Department of Science and Technology, Government of India, New Delhi, India, for financial assistance.

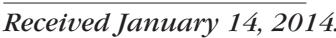




\section{REFERENCES}

1. K.A. McCall, Chih-chin Huang and C.A. Fierke, J. Nutr. 130, 1437S, (2000).

2. M.A. Taher, Talanta 52,181 (2000).

3. J.F.V. Staden, S.I. Tlowana, Talanta $58,1115,(2002)$.

4. Guidelines for Drinking Water Quality, Fourth Edition; World Health Organisation (WHO) (2011).

5. A.B. Tabrizi, Food Chem. 100, 1698 (2007).

6. J.M. Flinn, D. Hunter, D.H. Linkous, A. Lanzirotti, L.N. Smith, J. Brightwell and B.F. Jones, Physiol. Behav. 83, 793 (2005).

7. K.J. Reddy, J.R. Kumar, C. Ramachandraiah, T. Thriveni, and A. V. Reddy, Food Chem. 101, 585 (2007).

8. G. Gumus, H. Filik, and B. Demirata, Anal. Chim. Acta 547, 138 (2005).

9. J. Chen and K. C. Teo, Anal. Chim. Acta 450, 215 (2001).

10. L.S. G. Teixeira, M. de A. Bezerra, V. A. Lemos, H.C. dos Santos, D.S. de Jesus and A.C.S. Costa, Sep. Science and Tech. 40, 2555 (2005).

11. S.Y. Chen, C.N. Chang, C.L. Li, and S.J.J. Tsai, Anal. Chim. Acta 550, 156 (2005).

12. H. Minamisawa, K. Murashima, M. Minamisawa, N. Arai, and T. Okutani, Anal. Sci. 19, 401 (2003).

13. J.O. Romaní, A.M. Pineiro, P.B. Barrera and A.M. Esteban, Talanta 79, 723 (2009).

14. J. Fang, J.P. Chen,Y.H. Shu and H.P. Wang, Chinese J. of Physical Testing and Chemical Analysis B 12, 22 (2005).

15. A.A. Menegário, D.C Pellegrinotti, M.F. Giné and V.F.N Filho, Spectrochim. Acta B 58, 543 (2003).

16. L. A. Escudero L. D. Martinez, J.A. Salonia a, J. A. Gasquez, Microchem. J. 95, 164 (2010).

17. D. Kara, Anal. Letters 44, 457 (2011).

18. B. Erdem, A. Ozcan, A. S. Ozcan, Applied Surface Sci. 256, 5422 (2010).
19. H.F. Maltez, M.A. Vieira, A.S. Ribeiro, A.J. Curtius and E. Carasek, Talanta 74, 586 (2008).

20. M. B. Amran, A.S. Panggabean, A.I Sulaeman and M.Rusnadi, Int. J. Environ. Res. 5(2), 531 (2011).

21. S.D. Cekic, H. Filik and R. Alak, Anal. Chim. Acta 505, 15 (2004).

22. A.Sabarudin, N. Lenghor, M. Oshima, L. Hakim, T. Takayanagi and Y.H. Gao, Talanta 72, 1609 (2007).

23. J.S. Carletto, K.C.D.P. Roux, H.F. Maltez, E. Martendal and E. Carasek, J. Hazard. Mater. 157, 88 (2008).

24. V.A. Lemos, M.A. Bezerra and F.A.C. Amorim, J. of Hazard. Mater. 157, 613 (2008).

25. R. Saxena and S. Saxena, Indian J. of Chem. 51A, 1567 (2012).

26. R. Saxena and S. Saxena, At. Spectrosc. 33(3), 83 (2012).

27. R. Saxena and S. Singh, At. Spectrosc. 34(5), 155 (2013).

28. M.B.I Amran, A.S. Panggabean, A. Sulaeman, and M. Rusnadi, Int. J. Environ. Res. 5(2), 531 (2011).

29. S. Pramanik, S. Dhara, S.S. Bhattacharyya and P. Chattopadhyay, Anal. Chim. Acta 556, 430 (2006).

30. J. Goldstein, Scanning Electron Microscopy and X-Ray Microanalysis, Kluwer Adacemic/Plenum Publishers, New York, USA, 689 (2003).

31. K.B. Nilsson, L. Eriksson, V.G. Kessler and I. Persson, J. of Molecular Liquids 131,113 (2007).

32. V.N. Alves, S.S.O. Borges, and N.M.M. Coelho, International J. of Anal. Chem. 2011,1 (2011).

33. A.M. Haji Shabani, S. Dadfarnia and T. Moosavinejad, Quim. Nova 32, 1202 (2009).

34. Y. Liu, Y.Guo, S. Meng, and X. Chang, Microchim. Acta 158, 239 (2007).

35. M. Ghaedi, K. Niknam, K. Taheri, H. Hossainian and M. Soylak, Food Chem. Toxicol. 48(3), 891 (2010).
36. L. Wei, X. Zhang, Y. Dai, J. Huang, Y.H. Xie, and K. Xiao, J. of Automated Methods and Management in Chemistry, Article ID 742319 , 5 pp. (2008), dot:10.1155/2008/742319.

37. D. Kara, Talanta 79, 429 (2009).

38. A.N. Anthemidis, G.A. Zachariadis and J.A. Stratis, Intern. J. Environ. Anal. Chem. 90, 127 (2010).

39. R.J. Cassella, O.I. Magalhães, M.T. Couto, E.L. Lima, M.A. Neves and F.M. Coutinho, Anal. Sci. 8, 939 (2005). 